\title{
Ecological Risk Assessment of Pharmaceuticals and Personal Care Products in the Water Environment of 15 Cities in Japan
}

TAKAHIRO NISHINO ( $\square$ nishino-t@tokyokankyo.jp)

Tokyo Metropolitan Research Institute for Environmental Protection https://orcid.org/0000-0002-3927-2949

Mika Kato

Tokyo Metroporitan Research Institute for Environmental Protection

Yoshitaka Miyazawa

Tokyo Metropolitan Research Institute for Environmental Protection

Toshiki Tojo

Osaka City Research Center of Environmental Science

Daichi Asakawa

Osaka City Research Center of Environmental Sciences

Masanori Okata

Osaka City Research Center of Environmental Sciences

Chisato Matsumura

Hyogo Prefectual Institute of Environmental Sciences

Yuki Haga

Hyogo Prefectural Institute of Environmental Sciences

Takuya Kakoi

Hyogo Prefectural Institute of Environmental Sciences

Hitomi Hasegawa

Nagoya City Environmental Science Research Institute

Tetsuro Okamura

IDEA Consultants, Inc, Institute of Environmental Ecology

Atsushi Sawai

IDEA Consultants, Inc, Institute of Environmental Ecology

\section{Research Article}

Keywords: Pharmaceuticals and Personal Care Products, Risk assessment, Predicted No-Effect Concentration, Sewage Treatment Plant, Mass Balance, Bioassay Experiments

Posted Date: August 10th, 2021

DOl: https://doi.org/10.21203/rs.3.rs-719999/v1

License: (c) (1) This work is licensed under a Creative Commons Attribution 4.0 International License. Read Full License 


\section{Abstract}

To assess the ecological risk of pharmaceuticals and personal care products (PPCPs) to the water environment of several cities in Japan, major local environmental research institutes, a private company, and an academic institution launched a joint research project in 2019. Under this initiative, local environmental research institutes surveyed the concentrations of 46 types of PPCPs at 59 points distributed across 15 cities in Japan. IDEA Consultants, Inc. calculated the unknown values of predicted no-effect concentration (PNEC) of six chemicals (telmisartan, candesartan, fexofenadine, diphenhydramine, diphenyl sulfone, and ketotifen) through bioassay experiments on aquatic organisms. Among the researched chemicals, the concentrations of clarithromycin, 14-hydroxyclarithromycin, erythromycin, diclofenac, carbamazepine, and telmisartan exceeded the PNEC in at least one sampling point. However, ozone treatment removed most of these chemicals, except for certain phosphate ester flame retardants. The mass balance of chemicals in the Tamagawa River flowing through Tokyo Prefecture was calculated by multiplying the concentration of each chemical with the flow rate at each sampling point in the river. The measured load of most chemicals at each sampling point of the Tamagawa River coincided to a certain extent with the cumulative load accumulated from the tributaries and sewage treatment plants to the uppermost point (Nagata Bridge). However, the measured load of diclofenac was significantly smaller than the estimated values at each sampling point, suggesting that diclofenac photodegrades while flowing down the river.

\section{Introduction}

Chemicals such as drugs, cosmetics, pesticides, and fertilizers are essential to maintain the current lifestyle of most societies worldwide. However, several of these chemicals are potential environmental pollutants (such as dioxins, polychlorinated biphenyls, and dichlorodiphenyltrichloroethane) and adversely affect resources and living beings (Carson 1962; Eskenazi et al. 2018; Yoshimura 2003). Various laws, including the Water Pollution Control Law, Air Pollution Control Law, and Act on the Regulation of Manufacture and Evaluation of Chemical Substances, have been passed in Japan to control environmental pollution derived from such chemicals. Accordingly, responsible management of chemicals is steadily progressing, and the concentrations of several chemicals in the environment have decreased (Government of Japan 2012; United Nations Environment Programme 2016). However, pharmaceuticals and personal care products (PPCPs), commonly used in our daily lives, have not been subjected to regulation despite being detected in many water bodies throughout Japan. Many studies on PPCPs in water environments, including ecological risk assessments, have been conducted both domestically and internationally; e.g., in Asia (Kim et al. 2007; Harada et al. 2008; Kim et al. 2009; Komori et al. 2013; Zhou and Broodbank 2014; Xie et al. 2015; Ma et al. 2016; Mano and Okamoto 2016; Ma et al. 2017; Miyawaki et al. 2021), Europe (Loos et al. 2007; Kasprzyk-Hordern et al. 2008; Kasprzyk-Hordern et al. 2009; Houtman 2010; Carmona et al. 2014), Australia (Birch et al. 2015; Roberts et al. 2016), North America (Blair et al. 2013; García et al. 2014; Cizmas et al. 2015), and Africa (Agunbiade and Moodley 2014; Archer et al. 2017). In Japan, the Ministry of the Environment is leading efforts to clarify the actual state of PPCP pollution. A joint research project named "Contamination of the Aquatic Environment by Pharmaceutical and Personal Care Products: Environmental Risk Assessment and Removal from Wastewater" backed by "The Environment Research and Technology Development Fund" of the Environmental Restoration and Conservation Agency of Japan was launched in the 2019 fiscal year. In this research project, four regional environmental research institutes located in main cities of Japan (Tokyo Metropolitan Research Institute for Environmental Protection, Osaka City Research Center of Environmental Sciences, Hyogo Prefectural Institute of Environmental Sciences in Kobe, and Nagoya City Environmental Science Research Institute), a company (IDEA Consultants, Inc.), and an academic institution worked in collaboration to assess the actual pollution and ecological risk of a wide range of these chemicals in the country. The local environmental research institutes investigated the PPCP contamination values, and the private company performed the toxicity assessment to provide information for the ecological risk assessment. Additionally, 11 regional environmental research institutes also cooperated in water sampling. This was the first time in Japan that a wideranging survey and risk assessment of PPCPs in the water environment across 15 areas were conducted.

Sewage treatment plants (STPs), known to be one of the main sources of PPCPs in aquatic environments (Kasprzyk-Hordern et al. 2008; Kasprzyk-Hordern et al. 2009; Kim et al. 2009; Zhou et al. 2009; Roberts et al. 2016; Archer et al. 2017), were also analyzed in this study. The effluent and influent samples of six STPs were used to evaluate the PPCP emissions and investigate the removal efficiencies of the STPs. In addition, the daily mass of PPCPs was calculated based on the flow rate and their respective concentrations in the Tamagawa River flowing through Tokyo, and it was determined whether chemicals were stable when flowing down the river. This paper aimed to report the most important results obtained from this joint research project.

\section{Materials And Methods}

\subsection{Reagents}

Table 1 shows the chemicals analyzed in this study, which include pharmaceuticals such as antibiotics, antihypertensives, and antihistamines, and phosphate ester flame retardants (PFRs); these were selected based on the comprehensive analysis of former research (Environmental Restoration and Conservation Agency of Japan 2020) while considering their high consumption and frequent detection in aquatic environments. Information on the primary use or origin of each chemical was collected from several sources (DrugBank, ChemIDplus Advanced, and PubChem). Deuterium or ${ }^{13} \mathrm{C}$ labeled analytes were used in surrogates to maintain the highest quantitative accuracy for the analysis. 
Table 1

Chemicals analyzed in this study.

\begin{tabular}{|c|c|c|c|}
\hline \multicolumn{4}{|l|}{ Pharmaceuticals } \\
\hline Chemical & CAS RN & Main use or origin & Surrogate \\
\hline clarthromycin & $81103-11-9$ & Antibiotic ${ }^{a}$ & clarithromycin- ${ }^{13} \mathrm{C}, \mathrm{d}_{3}$ \\
\hline 14-hydroxyclarithromycin & $110671-78-8$ & Metabolite of clarithromycin & clarithromycin- ${ }^{13} \mathrm{C}, \mathrm{d}_{3}$ \\
\hline erythromycin & $114-07-8$ & Antibiotic $^{a}$ & erythromycin- $-{ }^{13} \mathrm{Cd}_{3}$ \\
\hline trimethoprim & $738-70-5$ & Antibiotic $^{a}$ & diphenhydramine- $d_{6}$ \\
\hline diclofenac & $15307-86-5$ & Anti-inflammatory drug ${ }^{a}$ & diclofenac-d 4 \\
\hline 5-hydroxydiclofenac & $69002-84-2$ & Metabolite of diclofenac & diclofenac- $d_{4}$ \\
\hline sulpiride & 15676-16-1 & Antipsychotic agent ${ }^{b}$ & sulpiride- $d_{3}$ \\
\hline carbamazepine & $298-46-4$ & Anticonvulsant ${ }^{a)}$ & carbamazepine- $\mathrm{d}_{8}$ \\
\hline 2-hydroxycarbamazepine & $68011-66-5$ & Metabolite of clabamazepine & carbamazepine-d 8 \\
\hline 3-hydroxycarbamazepine & $68011-67-6$ & Metabolite of clabamazepine & carbamazepine-d 8 \\
\hline carbamazepine-10,11-epoxide & $36507-30-9$ & Metabolite of clabamazepine & carbamazepine- $\mathrm{d}_{8}$ \\
\hline fexofenadine & $83799-24-0$ & Antihistamine $\mathrm{a}^{\mathrm{a}}$ & fexofenadine- $d_{6}$ \\
\hline epinastine & $80012-43-7$ & Antihistamine $\mathrm{a}^{\mathrm{a}}$ & diphenhydramine- $d_{6}$ \\
\hline ketotifen & $34580-13-7$ & Antihistamine ${ }^{a}$ & diphenhydramine- $d_{6}$ \\
\hline diphenhydramine & $58-73-1$ & Antihistamine ${ }^{a}$ & diphenhydramine- $d_{6}$ \\
\hline diphenylsulfone & $127-63-9$ & Pesticide, dyes ${ }^{c}$ & losartan- $\mathrm{d}_{4}$ \\
\hline telmisartan & $144701-48-4$ & Antihypertensive agent ${ }^{\mathrm{b}}$ & telmisartan- $d_{7}$ \\
\hline irbesartan & $138402-11-6$ & Antihypertensive agent ${ }^{\mathrm{b}}$ & irbesartan- $d_{7}$ \\
\hline olmesartan & $144689-24-7$ & Antihypertensive agent ${ }^{\mathrm{b}}$ & olmesartan- $\mathrm{d}_{6}$ \\
\hline valsartan & $137862-53-4$ & Antihypertensive agent ${ }^{\mathrm{b}}$ & valsartan- $d_{9}$ \\
\hline losartan & $114798-26-4$ & Antihypertensive agent ${ }^{\mathrm{b}}$ & losartan- $\mathrm{d}_{4}$ \\
\hline candesartan & $139481-59-7$ & Antihypertensive agent ${ }^{\mathrm{b}}$ & valsartan- $d_{9}$ \\
\hline crotamiton & $483-63-6$ & Anti-parasite medicine $\mathrm{a}^{\mathrm{a}}$ & crotamiton-d $\mathrm{d}_{5}$ \\
\hline N,N-diethyl-m-toluamide (DEET) & $134-62-3$ & Insect repellent ${ }^{\mathrm{b}}$ & DEET- $_{6}$ \\
\hline \multicolumn{4}{|l|}{ Phosphate ester flame retardants (PFRs) } \\
\hline Chemical & CAS RN & Main use or origin & Surrogate \\
\hline triethyl phosphate (TEP) & $78-40-0$ & Flame retardant, Adhesive ${ }^{c}$ & TEP-d $_{15}$ \\
\hline tris(2-chloroethyl) phosphate (TCEP) & $115-96-8$ & Flame retardant, Adhesive ${ }^{c}$ & TCEP-d $\mathrm{d}_{12}$ \\
\hline tris(2-choroisopropyl) phosphate (TCPP) & $13674-84-5$ & Flame retardant, Adhesive ${ }^{c}$ & TCPP-d $_{18}$ \\
\hline tris(1,3-dichloro-2-propyl) phosphate (TDCPP) & $13674-87-8$ & Flame retardant, Plasticizer ${ }^{\mathrm{C}}$ & TDCPP- $_{15}$ \\
\hline tributyl phosphate (TBP) & $126-73-8$ & Flame retardant, Solvent ${ }^{c}$ & TBP-d 27 \\
\hline triphenyl phosphate (TPhP) & $115-86-6$ & Adhesive, Antifouling ${ }^{c}$ & TPhP-d 15 \\
\hline tris(2-butoxyethyl) phosphate (TBOEP) & $78-51-3$ & Flame retardant, Plasticizer ${ }^{\mathrm{C}}$ & TBOEP-d $_{12}$ \\
\hline tricresyl phosphate (TCP) & $1330-78-5$ & Flame retardant, Plasticizer ${ }^{\mathrm{C}}$ & TCP-d 21 \\
\hline
\end{tabular}




\begin{tabular}{|l|}
\hline Pharmaceuticals \\
\hline bSource: ChemIDplus Advanced \\
\hline 'Source: Pubchem \\
\hline
\end{tabular}

Pharmaceutical-grade chemicals were purchased from several suppliers, including Fujifilm Wako Pure Chemical (Osaka, Japan), Tokyo Chemical Industry Co., Ltd. (Tokyo, Japan), Cambridge Isotope Laboratories, Inc. (Tewksbury, MA, USA), and Hayashi Pure Chemicals (Osaka, Japan). The solvents used for the chemical extraction were residual pesticides of analytical grade (Kanto Chemicals, Tokyo Japan), and the ones used for the Liquid chromatograph-Mass spectrometer (LC-MS/MS) analysis were of LC/MS grade or high-performance liquid chromatographic grade (Kanto Chemicals; Fujifilm Wako Pure Chemical).

For the analysis of pharmaceuticals, standard chemicals were individually dissolved with methanol at $100-1000 \mathrm{ng} \mathrm{mL}^{-1}$ as the first solution, which was then mixed and diluted to $1.0 \mathrm{ng} \mathrm{mL}^{-1}$ with methanol. The surrogate mixture solution was prepared by a similar method. To prepare the standard PFRs and their surrogates, mixture solutions (Hayashi Pure Chemicals) were purchased and prepared using the same method as that employed for the pharmaceutical samples.

\subsection{Solid-phase extraction}

\subsubsection{Pharmaceuticals}

Oasis-HLB plus (225 mg; Waters Associates, Milford, MA, USA) was used in the solid-phase cartridge to extract pharmaceuticals. The cartridge was preconditioned with $5 \mathrm{~mL}$ of acetone followed by $10 \mathrm{~mL}$ of ultrapure water. After adding $10 \mu \mathrm{L}$ of the surrogate mixture solution (1.0 mg L $\mathrm{L}^{-1}$ for each chemical) to $200 \mathrm{~mL}$ of river water samples ( 50 and $100 \mathrm{~mL}$ for STP influents and effluents, respectively), the samples were loaded to the solid-phase cartridges at a flow rate of $10 \mathrm{~mL} \mathrm{~min}{ }^{-1}$. The cartridge was then washed with $30 \mathrm{~mL}$ of ultrapure water and dried using centrifugation (2000 rpm, $5 \mathrm{~min}$ ) and a nitrogen gas flush.

The chemicals were eluted from the dried cartridge using $3 \mathrm{~mL}$ of methanol, followed by the addition of $3 \mathrm{~mL}$ of acetone and $2 \mathrm{~mL}$ of dichloromethane; these three solvents were mixed in a 10-mL glass tube. The mixed solvent was concentrated with nitrogen gas to approximately $0.1 \mathrm{~mL}$ and adjusted to $1 \mathrm{~mL}$ with $80 \%$ methanol aqueous solution. The solution was filtered with a syringe filter (Millex®-LG, pore size: $0.2 \mu$ m, diameter: 4 mm; Merck Millipore Corporation, Burlington, MA, USA) and analyzed with LC-MS/MS (Xevo-TQS: Waters Associates). Fig. S1 (Online Resource 1) shows the analysis procedure for the pharmaceuticals.

\subsubsection{PFRs}

Plastic materials were avoided in the extraction of PFRs since certain PFRs exhibit plasticizer properties. InertSep Glass PLS-3 (200 mg/6 mL) was used for PFR extraction after being preconditioned with $8 \mathrm{~mL}$ of methanol followed by $10 \mathrm{~mL}$ of ultrapure water. To analyze the water samples, $10 \mu \mathrm{L}$ of surrogate mixture solution ( $1.0 \mathrm{mg} \mathrm{L}^{-1}$ for each chemical) was added to $200 \mathrm{~mL}$ of river water samples (50 mL for STP influents, and $100 \mathrm{~mL}$ for STP effluents); the subsequent mixture was poured into a polypropylene container connected to a concentrator. Although plastic materials were avoided in the PFRs analysis, glass containers were excessively heavy and unstable to be connected to a concentrator.

Before the extraction, the containers were thoroughly washed with ultrapure water and methanol. The samples were loaded to the solid-phase cartridges at 10 $\mathrm{mL} \mathrm{min}^{-1}$. The cartridge was then washed with $10 \mathrm{~mL}$ of ultrapure water and dried with a flush of nitrogen gas. The chemicals were eluted from the dried cartridge with $8 \mathrm{~mL}$ of acetone. The solvent was concentrated with nitrogen gas to approximately $0.1 \mathrm{~mL}$ and adjusted with $1 \mathrm{~mL}$ of methanol. The solution was filtered with a syringe filter (Millex®-LG, pore size: $0.2 \mu \mathrm{m}$, diameter: $4 \mathrm{~mm}$; Merck Millipore Corporation) and analyzed with LC-MS/MS (Xevo-TQS: Waters Associates). Fig. S2 (Online Resource 1) shows the analysis procedure for PFRs, and Table S1 (Online Resource 1) shows the LC-MS/MS analysis conditions for pharmaceuticals and PFRs.

\subsection{Quality control}

Recovery tests were conducted as quality tests using STP effluent and ultrapure water. The method detection limits (MDLs) and method quantification limits (MQLs) were estimated based on data from eight different analyses of the standard PPCP mixture added to ultrapure water at 0.5 and $5.0 \mathrm{ng} \mathrm{L}^{-1}$.

\subsection{PNECS of PPCPs}

For the risk assessment, the measured value of each analyte was compared with the respective predicted no-effect concentration (PNEC) obtained from the literature (Harada et al. 2008; Environment Agency of UK 2009; The National Research and Development Agency Public Works Research Institute 2010; Verlicchi et al. 2012; Deo et al. 2013; Komori et al. 2013; Furberg 2014; Baumann et al. 2015; Mano et al. 2016) and from the official websites of the European Chemical Agency and Ministry of Environment, Japan. A summary of PNEC information is shown in Table 2. The PNEC values for the same chemical varied significantly among different references. For example, the PNEC of diclofenac varied from 1000 (Furberg 2014) to 10000 (Komori et al. 2013 ). In this study, the smallest values were adopted for the risk assessment to ensure a higher safety standard. The PNECs of six chemicals (telmisartan, candesartan, fexofenadine, diphenhydramine, diphenyl sulfone, and ketotifen) have not been widely investigated. Therefore, IDEA Consultants, Inc., calculated them through experiments on aquatic organisms under the test guidelines TG-212 for fishes and TG-201 for algae (Organization for Economic Cooperation and Development 1998, 2011) while using the biological test method for crustaceans (Ceriodaphnia dubia) (Environment Canada 2007). The No Observed Effect Concentration (NOEC) of the investigated species was elucidated based on the bioassay data. The PNEC of each chemical was then calculated based on the lowest NOEC among the three species by using an assessment factor.

Page $4 / 15$ 
Table 2

Predicted no effect concentrations of chemicals analyzed in this study.

\begin{tabular}{|c|c|c|c|c|c|c|c|c|c|c|c|}
\hline \multirow[t]{2}{*}{ Chemical } & \multicolumn{11}{|c|}{ Reference } \\
\hline & $\begin{array}{l}\text { Furberg } \\
2014\end{array}$ & $\begin{array}{l}\text { Deo } \\
\text { et al. } \\
2013\end{array}$ & $\begin{array}{l}\text { Komori } \\
\text { et al. } \\
2013\end{array}$ & $\begin{array}{l}\text { Harada } \\
\text { et } \\
\text { al. } 2008\end{array}$ & $\begin{array}{l}\text { Verlicchi } \\
\text { et al. } \\
2012\end{array}$ & $\begin{array}{l}\text { Baumann } \\
\text { et al. } \\
2015\end{array}$ & $\begin{array}{l}\text { Mano } \\
\text { et al. } \\
2016\end{array}$ & $\begin{array}{l}\text { European } \\
\text { Chemical } \\
\text { Agency }\end{array}$ & $\begin{array}{l}\text { Initial risk } \\
\text { assessment } \\
\text { by the } \\
\text { Ministry of } \\
\text { Environment, } \\
\text { Japan }\end{array}$ & $\begin{array}{l}\text { Aquatic } \\
\text { toxicity tests } \\
\text { of chemicals } \\
\text { conducted } \\
\text { by the } \\
\text { Ministry of } \\
\text { Environment, } \\
\text { Japan }\end{array}$ & $\begin{array}{l}\text { National } \\
\text { Research } \\
\text { and } \\
\text { Developr } \\
\text { Agency } \\
\text { Public W } \\
\text { Research } \\
\text { Institute, } \\
\text { Japan, } 2\end{array}$ \\
\hline clarithromycin & & & 52 & 50 & 70 & & 20 & & 69 & & 20 \\
\hline $\begin{array}{l}\text { 14- } \\
\text { hydroxyclarithromycin }\end{array}$ & & & & & & 270 & & & & & \\
\hline erythromycin & & 20 & & & 20 & & & & 360 & & 100 \\
\hline trimethoprim & & 1000 & & & 2600 & & & & & & 60000 \\
\hline diclofenac & 66.3 & & 10000 & 460 & 9700 & & & & 1100 & & 5000 \\
\hline carbamazepine & 29.7 & 420 & 250 & & 13800 & & & & & & 5200 \\
\hline \multicolumn{12}{|l|}{ fexofenadine } \\
\hline \multicolumn{12}{|l|}{ ketotifen } \\
\hline \multicolumn{12}{|l|}{ diphenhydramine } \\
\hline diphenyl sulfone & & & & & & & & 50000 & & & \\
\hline \multicolumn{12}{|l|}{ telmisartan } \\
\hline \multicolumn{12}{|l|}{ candesartan } \\
\hline crotamiton & & & 21000 & 20830 & & & 3500 & & & & 3500 \\
\hline $\begin{array}{l}\text { N,N-diethyl-m- } \\
\text { toluamide (DEET) }\end{array}$ & & & 5200 & 5210 & & & & & & & 5200 \\
\hline $\begin{array}{l}\text { triethylphosphate } \\
\text { (TEP) }\end{array}$ & & & & & & & & 632000 & & & \\
\hline $\begin{array}{l}\text { tris(2- } \\
\text { chloroethyl)phosphate } \\
\text { (TCEP) }\end{array}$ & & & & & & & & & 100000 & & \\
\hline $\begin{array}{l}\text { tris(2-choroisopropyl) } \\
\text { phosphate (TCPP) }\end{array}$ & & & & & & & & $\begin{array}{l}420000- \\
640000\end{array}$ & & & \\
\hline $\begin{array}{l}\text { tris(1,3-dichloro-2- } \\
\text { propyl) phosphate } \\
\text { (TDCPP) }\end{array}$ & & & & & & & & 200 & & & \\
\hline $\begin{array}{l}\text { tributyl phosphate } \\
\text { (TBP) }\end{array}$ & & & & & & & & $\begin{array}{l}35000- \\
82000\end{array}$ & 11000 & & \\
\hline $\begin{array}{l}\text { triphenyl phosphate } \\
\text { (TPhP) }\end{array}$ & & & & & & & & 3700 & 3000 & & \\
\hline $\begin{array}{l}\text { tris(2-butoxyethyl) } \\
\text { phosphate (TBOEP) }\end{array}$ & & & & & & & & 24000 & & 21000 & \\
\hline $\begin{array}{l}\text { tricresyl phosphate } \\
\text { (TCP) }\end{array}$ & & & & & & & & 1000 & 1500 & & \\
\hline
\end{tabular}

Among the predicted no-effect concentrations (PNECs) of TBOEP, $21000 \mathrm{ng} \mathrm{L}^{-1}$ was calculated by dividing the acute toxicity data for fish (Oryzias latipes) of factor of 1000, following the guidelines of the Initial Environment Risk Assessment of Chemicals.

The PNEC of 14-hydroxyclarithromycin, $270 \mathrm{ng} \mathrm{L}^{-1}$ was calculated by dividing the chronic toxicity data for algae (Anabena flos-aquae) of $2.7 \mu \mathrm{L} \mathrm{L}^{-1}$ (NOEC) the guidelines of the Initial Environmental Risk Assessment of Chemicals in Japan.

For each chemical, the PNEC used for the risk assessment in this study is highlighted and written in bold.

\subsection{River water samples}

The total number of sampling points was 59. The water samples were collected by hanging a stainless-steel bucket from either the bridge or shore for each sampling point from July to September 2019. If the sampling point was influenced by the ebb and flow of the tide, sampling was conducted during the low tide. The collected samples were sent to the Tokyo Metropolitan Research Institute for Environmental Protection under refrigeration. The received samples 
were immediately processed by a solid-phase extraction method and then analyzed using LC-MS/MS. The sampling points of this study (considering the four institutes participating in this joint research) are shown in Table S2 (Online Resource 1) and Fig. S3 (Online Resource 1).

\subsection{PPCPs in STPs}

As STPs are known sources of PPCPs (Archer et al. 2017; Balakrishna et al. 2017), influent and effluent water samples from six STPs were collected, and their PPCP removal efficiencies were evaluated by comparing the concentration of pollutants in the influent and effluent samples. The researched STPs use an anaerobic-anoxic-oxic process for wastewater treatment. All effluent and influent STP samples analyzed in this study were composite samples prepared by mixing sample fractions collected every $2 \mathrm{~h}$ over a $24 \mathrm{~h}$ period. This approach considers the variability of pollution load throughout the day.

\subsection{Mass balance of chemicals in the Tamagawa River in Tokyo}

The mass balance of six chemicals, whose concentrations exceeded PNEC in at least one sampling point, was calculated for the Tamagawa River flowing through Tokyo.

The Tamagawa River has a simple channel because its flow is not influenced by the tide from the Chofu water intake, and it does not branch out until its estuary (Fig. 1). Furthermore, its shallowness allows the flow velocity entering the river channel to be measured more conveniently. The width of the Tamagawa River was first measured, then divided into 10-12 sections, and finally, the flow velocity of each section was measured using a current meter. When the depth of each sampling point was $\geq 40 \mathrm{~cm}$, the flow velocity was measured at two depth points: $20 \%$ and $80 \%$ of the depth from the surface to the bottom; when the depth was $<40 \mathrm{~cm}$, it was measured at $60 \%$ of the depth. The flow rates from the STPs were obtained from the Tokyo Bureau of Sewerage.

\section{Results And Discussion}

\subsection{Quality control}

Recovery rates, calculated by subtracting the concentration of the sample without the chemical from that of the sample with the chemicals added, was within the ranges of $71-143 \%$ (average: $98 \%$ ) and $61-147 \%$ (average: $99 \%$ ) for ultrapure water and the STP effluent, respectively.

\subsection{Calculation of MDLs and MQLs}

The MDLs and MQLs of the analyzed chemicals were calculated based on the results of the recovery tests conducted by adding the chemicals to ultrapure water and adjusting the concentration at the lowest calibration curve level. Eight extracted samples were analyzed with LC-MS/MS, and the respective t-values were calculated based on the standard deviation for each chemical. The MDLs and MQLs were calculated using the following formulas (Currie 1997$)$ : $M D L=2$ $\times t(n-1,0.05) \times \sigma_{n-1} \times 2$, and $M Q L=10 \times \sigma_{n-1} ;$ where $t(n-1,0.05)$ indicates the $t$-value (one-sided) for the risk factor of $5 \%$ and the degree of freedom of $n-1$.

\subsection{PNECs of PPCPs}

The assessment factors were obtained from the "Guidelines for the Initial Environmental Risk Assessment of Chemicals," published by the Ministry of Environment, Japan (2019). Following these guidelines, when chronic toxicity data were obtained for the three species (fish, algae, and crustacean), the assessment factor was 10; however, when chronic data were obtained for one or two species, the assessment factor was 100 . Among the three methods used to calculate PNECs, TG-212 is considered an acute toxicity test, while the others are chronic toxicity tests. Therefore, the assessment factor for the six analyzed chemicals was set at 100 .

Algae are highly susceptible to 14 -hydroxyclarithromycin, compared to other species, with half $(50 \%)$ maximal effective concentrations $(E C 50)>2000 \mu g L^{-1}$ for fish and EC50 > $2000 \mu \mathrm{g} \mathrm{L}^{-1}$ for crustaceans; the concentration that results in $50 \%$ inhibition of growth rate (ErC50) of algae is $27.2 \mu \mathrm{g} \mathrm{L} \mathrm{L}^{-1}$ (Baumann et al. 2015). In this case, according to the guideline published by the Ministry of Environment, Japan (2019), the assessment factor can be assumed to be 10. Therefore, the PNEC of 14-hydroxyclarithromycin was set at $270 \mathrm{ng} \mathrm{L}^{-1}$, calculated by dividing the lowest NOEC $\left(2.7 \mu \mathrm{g} \mathrm{L}^{-1}\right)$ by the assessment factor of 10 . Similarly, for tris(2-butoxyethyl) phosphate (TBOEP), the minimum PNEC was calculated by dividing $21 \mathrm{mg} \mathrm{L}^{-1}$ ( $96 \mathrm{~h}$-lethal concentration for $50 \%$ of animals (LC50)) (obtained from the toxicity tests conducted by the Ministry of the Environment, Japan) by the assessment factor of 1000 .

\subsection{River water samples}

Analyzed data for PPCP detected at a concentration more than the PNEC of each chemical or $1000 \mathrm{ng} \mathrm{L}^{-1}$, in at least one sampling point, are shown in Table 3, and the details of the data are shown in Tables S3 and S4. The names of the municipalities were indicated with letters (A to K), and the sampling points in each municipality were assigned identification numbers (e.g., "A-1" or "C-5") based on the data obtained from the 11 institutes collaborating in this joint research. 
Table 3

Concentrations of pharmaceuticals and personal care products (PPCPs) in water environment samples (ng L- 1)

\begin{tabular}{|c|c|c|c|c|c|c|c|c|c|c|c|c|}
\hline \multicolumn{13}{|c|}{ Four institutes participating in this joint research project } \\
\hline $\begin{array}{l}\text { City or } \\
\text { Prefecture }\end{array}$ & River & & & 14- & erythro & diclofenac & carbama & sulpiride & fexo & diphenyl & telmisartan & va \\
\hline & & $\begin{array}{l}\text { Sampling } \\
\text { point }\end{array}$ & mycin & clarithro & mycin & & zepine & & fenadine & sulfone & & \\
\hline & & & & mycin & & & & & & & & \\
\hline \multirow[t]{2}{*}{ Osaka $\mathrm{C}^{\mathrm{a}}$} & $\begin{array}{l}\text { Daini } \\
\text { Neya }\end{array}$ & $\begin{array}{l}\text { Shigino- } \\
\text { ohashi Bridge }\end{array}$ & 600 & 580 & 100 & 45 & 42 & 890 & 2500 & 1200 & 860 & 44 \\
\hline & $\begin{array}{l}\text { gawa } \\
\mathrm{R}^{\mathrm{C}}\end{array}$ & $\begin{array}{l}\text { Shimoshiromi } \\
\text { Bridge }\end{array}$ & 570 & 510 & 370 & 45 & 36 & 760 & 2200 & 970 & 810 & 42 \\
\hline \multirow[t]{2}{*}{ Hyogo $\mathrm{P}^{\mathrm{b}}$. } & \multirow[t]{2}{*}{$\begin{array}{l}\text { Inagawa } \\
\text { R. }\end{array}$} & $\begin{array}{l}\text { Inagawa } \\
\text { Bridge }\end{array}$ & N.D. ${ }^{e}$ & N.D. & 57 & N.D. & 4.8 & 4.1 & N.D. & (2.5) & $(2.2)$ & $\mathrm{N}$. \\
\hline & & Tokura Bridge & 470 & 470 & 57 & 70 & 51 & 1000 & 3500 & 76 & 1300 & 18 \\
\hline \multirow[t]{2}{*}{$\begin{array}{l}\text { Nagoya } \\
\text { C. }\end{array}$} & \multirow{2}{*}{$\begin{array}{l}\text { Hori } \\
\text { kawa R. }\end{array}$} & $\begin{array}{l}\text { Johoku } \\
\text { Bridge }\end{array}$ & 340 & 330 & 23 & 17 & 22 & 400 & 2400 & 83 & 600 & 11 \\
\hline & & $\begin{array}{l}\text { Nakatsuchito } \\
\text { Bridge }\end{array}$ & 400 & 390 & 25 & 27 & 26 & 470 & 2900 & 83 & 730 & 11 \\
\hline \multirow[t]{2}{*}{ Tokyo P. } & \multirow{2}{*}{$\begin{array}{l}\text { Tama } \\
\text { gawa R. }\end{array}$} & $\begin{array}{l}\text { Nagata } \\
\text { Bridge }\end{array}$ & N.D. & N.D. & N.D. & N.D. & $(0.11)$ & N.D. & N.D. & N.D. & N.D. & $\mathrm{N}$. \\
\hline & & Hino Bridge & 180 & 220 & 30 & 29 & 39 & 360 & 1700 & 47 & 620 & 13 \\
\hline \multicolumn{13}{|c|}{11 institutes cooperating in this joint research project } \\
\hline \multirow{3}{*}{\multicolumn{2}{|c|}{ Institute }} & Chemical & clarithro & $\begin{array}{l}14- \\
\text { hydroxy }\end{array}$ & erythro & diclofenac & carbama & sulpiride & fexo & diphenyl & telmisartan & va \\
\hline & & $\begin{array}{l}\text { Sampling } \\
\text { point }\end{array}$ & mycin & clarithro & mycin & & zepine & & fenadine & sulfone & & \\
\hline & & & & mycin & & & & & & & & \\
\hline \multirow[t]{2}{*}{ A } & & $A-1$ & 35 & 39 & 40 & $(1.9)$ & 5.1 & 56 & 180 & 14 & 61 & 98 \\
\hline & & $A-2$ & 160 & 230 & 39 & 19 & 13 & 220 & 1600 & 63 & 270 & 78 \\
\hline \multirow[t]{2}{*}{ B } & & B-1 & 21 & 24 & 57 & (1.7) & 3.7 & 42 & 82 & 19 & 69 & 66 \\
\hline & & B-3 & 200 & 240 & N.D. & 21 & 21 & 480 & 1100 & 62 & 670 & 37 \\
\hline \multirow[t]{2}{*}{ C } & & C-3 & N.D. & N.D. & N.D. & N.D. & N.D. & N.D. & N.D. & (3.2) & N.D. & $\mathrm{N}$. \\
\hline & & C-4 & 750 & 910 & 370 & 140 & 72 & 1200 & 3600 & 120 & 2300 & 33 \\
\hline \multirow[t]{2}{*}{ D } & & D-2 & 15 & 20 & (3.4) & 4.4 & 5.5 & 43 & 67 & 19 & 50 & 77 \\
\hline & & D-3 & 360 & 390 & 57 & 69 & 38 & 480 & 1300 & 56 & 820 & 26 \\
\hline \multirow[t]{2}{*}{$E$} & & $\mathrm{E}-1$ & 510 & 540 & 57 & 120 & 60 & 970 & 2100 & 74 & 1300 & 24 \\
\hline & & $E-2$ & 58 & 59 & 9.8 & (2.8) & 10 & 100 & 230 & 26 & 200 & 10 \\
\hline \multirow[t]{2}{*}{$\mathrm{F}$} & & $\mathrm{F}-1$ & 79 & 88 & N.D. & 25 & 37 & 220 & 550 & 23 & 290 & 53 \\
\hline & & $F-2$ & 96 & 120 & 15 & 14 & 27 & 220 & 650 & 20 & 290 & 49 \\
\hline G & & G-1 & 9.5 & 10 & N.D. & 5.6 & 5.7 & 19 & 44 & N.D. & 49 & 37 \\
\hline \multirow[t]{2}{*}{$\mathrm{H}$} & & $\mathrm{H}-1$ & 72 & 75 & (3.8) & 12 & 6.2 & 81 & 320 & 14 & 130 & 11 \\
\hline & & $\mathrm{H}-2$ & 310 & 290 & 11 & 43 & 39 & 300 & 1200 & 41 & 490 & 18 \\
\hline \multirow[t]{2}{*}{1} & & I-1 & 9.1 & 12 & N.D. & 4.5 & 6.2 & 59 & 99 & 6.7 & 87 & (7. \\
\hline & & $\mathrm{I}-2$ & 28 & 34 & (5.1) & 25 & 22 & 230 & 520 & 17 & 400 & 59 \\
\hline \multirow[t]{2}{*}{$\mathrm{J}$} & & $\mathrm{J}-1$ & 3.0 & 3.0 & N.D. & 4.9 & 5.0 & 43 & 48 & N.D. & 39 & 18 \\
\hline & & $\mathrm{J}-2$ & 860 & 900 & 80 & 220 & 75 & 1400 & 3200 & 160 & 2200 & 30 \\
\hline \multirow[t]{2}{*}{ K } & & $\mathrm{K}-1$ & 2.4 & 2.3 & N.D. & N.D. & 4.4 & 6.2 & 23 & (4.1) & (4.3) & 22 \\
\hline & & $\mathrm{K}-2$ & 430 & 430 & 53 & 79 & 62 & 750 & 2300 & 57 & 810 & 28 \\
\hline
\end{tabular}




\begin{tabular}{|c|c|c|c|c|c|c|c|c|c|c|}
\hline \multicolumn{11}{|c|}{ Four institutes participating in this joint research project } \\
\hline Method Detection Limit (MDL) & 0.8 & 0.2 & 3.3 & 1.2 & 0.1 & 1.2 & 1.7 & 1.9 & 2.1 & $3 .^{\circ}$ \\
\hline Method Quantification Limit (MQL) & 2.2 & 0.7 & 8.7 & 3.3 & 0.2 & 3.3 & 4.6 & 5.0 & 5.6 & $8 .^{\circ}$ \\
\hline $\begin{array}{l}\text { Predicted no-effect concentration } \\
\text { (PNEC) }\end{array}$ & 20 & 270 & 20 & 66 & 30 & $>>100000$ & 300000 & 3500 & 1600 & - \\
\hline
\end{tabular}

a: City, b: Prefecture, c: River, d: tris(2-butoxyethyl) phosphate, e: not detected

The blank test value was subtracted from the raw measured values for $N, N$-diethyl- $m$-toluamide (DEET) and diphenyl sulfone because the blank test values were above the MDL for both chemicals. The gray cells shown in Table 3 indicate that the measured values exceeded the respective PNECs. The concentrations of clarithromycin, 14-hydroxyclarithromycin, erythromycin, carbamazepine, diclofenac, and telmisartan exceeded their respective PNECs at several sampling points, and almost all these points were in the downstream areas.

For risk assessment, the concentrations of these chemicals were compared with their respective PNECs. Among the chemicals studied, carbamazepine and diclofenac are the most frequently researched in previous studies (Bendz et al. 2005; Kim et al. 2007; Kim et al. 2009; Agunbiade and Moodley 2014; Olaitan et al. 2014; Zhou and Broodbank 2014; Xie et al. 2015; Ma et al. 2016; Ma et al. 2017). The concentrations of these chemicals were nearly the same as or lower than those reported in previously published studies.

\subsection{Removal efficiency of STPS}

Table 4 shows the PPCP concentrations at each process step in the six investigated STPs. The removal rates of the macrolide antibiotics, i.e., clarithromycin, 14-hydroxyclarithromycin, and erythromycin, were approximately $24-53 \%$ (35\% on average), $18-57 \%$ ( $36 \%$ on average), and - 59-84\% (- $10 \%$ on average), respectively. The concentration of erythromycin in the effluent of F STP was below the MQL. As mentioned above, all effluent and influent STP samples analyzed in this study were composite samples used to determine the average variability of pollution load throughout the day. However, when preparing composite samples, sampling of both influent and effluent fractions starts simultaneously. In typical STPs, there is a time lag of 6-8 $\mathrm{h}$ even only for a reactor in which conventional activated-sludge treatment is conducted (Japan Sewage Works Association 2013). Therefore, even for composite samples, the gap due to time lag cannot be compensated totally. 
Table 4

Concentrations of the pharmaceuticals and personal care products (PPCPs) at each process in the six sewage treatmer

\begin{tabular}{|c|c|c|c|c|c|c|c|c|c|c|c|}
\hline $\begin{array}{l}\text { Chemical } \\
\text { STPs }\end{array}$ & $\begin{array}{l}\text { clarithro } \\
\text { mycin }\end{array}$ & $\begin{array}{l}14- \\
\text { hydroxy } \\
\text { clarithro } \\
\text { mycin }\end{array}$ & $\begin{array}{l}\text { erythro } \\
\text { mycin }\end{array}$ & $\begin{array}{l}\text { trimetho } \\
\text { prim }\end{array}$ & $\begin{array}{l}\text { diclo } \\
\text { fenac }\end{array}$ & $\begin{array}{l}\text { 5- } \\
\text { hydroxy } \\
\text { diclo } \\
\text { fenac }\end{array}$ & sulpiride & $\begin{array}{l}\text { carbama } \\
\text { zepine }\end{array}$ & $\begin{array}{l}2- \\
\text { hydroxy } \\
\text { carbama } \\
\text { zepine }\end{array}$ & $\begin{array}{l}\text { 3- } \\
\text { hydroxy } \\
\text { carbama } \\
\text { zepine }\end{array}$ & $\begin{array}{l}\text { carbamazepine } \\
10,11 \\
\text { epoxide }\end{array}$ \\
\hline $\begin{array}{l}\text { A ozonized } \\
\text { water }\end{array}$ & 5.4 & 8.2 & N.D. ${ }^{a}$ & N.D. & N.D. & 39 & 140 & $(0.23)$ & N.D. & 4.9 & 28 \\
\hline A effluent & 540 & 540 & 59 & 120 & 180 & 110 & 1300 & 91 & 61 & 63 & 57 \\
\hline A influent & 730 & 850 & 40 & 210 & 250 & 220 & 1600 & 81 & 48 & 50 & 33 \\
\hline $\begin{array}{l}\text { Removal rate } \\
\text { by ozone (\%) }\end{array}$ & $99 \%$ & $98 \%$ & $100 \%$ & $100 \%$ & $100 \%$ & $64 \%$ & $89 \%$ & $100 \%$ & $100 \%$ & $92 \%$ & $50 \%$ \\
\hline $\begin{array}{l}\text { Removal rate } \\
(\%)\end{array}$ & $26 \%$ & $36 \%$ & $-49 \%$ & $43 \%$ & $28 \%$ & $50 \%$ & $19 \%$ & $-12 \%$ & $-26 \%$ & $-26 \%$ & $-73 \%$ \\
\hline B effluent & 740 & 840 & 31 & 150 & 210 & 190 & 1400 & 120 & 86 & 85 & 76 \\
\hline B influent & 980 & 1100 & 31 & 240 & 230 & 230 & 1600 & 97 & 67 & 62 & 50 \\
\hline $\begin{array}{l}\text { Removal rate } \\
(\%)\end{array}$ & $24 \%$ & $24 \%$ & $-1 \%$ & $38 \%$ & $9 \%$ & $17 \%$ & $13 \%$ & $-24 \%$ & $-28 \%$ & $-38 \%$ & $-51 \%$ \\
\hline C effluent & 620 & 770 & 67 & 120 & 160 & 160 & 1400 & 85 & 72 & 73 & 64 \\
\hline $\mathrm{C}$ influent & 840 & 940 & 42 & 150 & 200 & 230 & 1400 & 84 & 66 & 64 & 51 \\
\hline $\begin{array}{l}\text { Removal rate } \\
\text { (\%) }\end{array}$ & $26 \%$ & $18 \%$ & $-59 \%$ & $20 \%$ & $20 \%$ & $30 \%$ & $0 \%$ & $-1 \%$ & $-10 \%$ & $-14 \%$ & $-25 \%$ \\
\hline D effluent & 390 & 420 & 23 & 75 & 180 & 140 & 1200 & 89 & 66 & 77 & 64 \\
\hline D influent & 750 & 970 & 23 & 210 & 210 & 220 & 1200 & 69 & 64 & 62 & 54 \\
\hline $\begin{array}{l}\text { Removal rate } \\
(\%)\end{array}$ & $48 \%$ & $57 \%$ & $-1 \%$ & $64 \%$ & $14 \%$ & $37 \%$ & $0 \%$ & $-30 \%$ & $-3 \%$ & $-24 \%$ & $-18 \%$ \\
\hline E effluent & 510 & 630 & 76 & 110 & 150 & 140 & 1100 & 78 & 53 & 55 & 47 \\
\hline E influent & 790 & 910 & 58 & 170 & 170 & 180 & 1200 & 77 & 53 & 44 & 33 \\
\hline $\begin{array}{l}\text { Removal rate } \\
(\%)\end{array}$ & $35 \%$ & $31 \%$ & $-31 \%$ & $35 \%$ & $12 \%$ & $22 \%$ & $8 \%$ & $-2 \%$ & $0 \%$ & $-25 \%$ & $-45 \%$ \\
\hline F effluent & 520 & 670 & (7.6) & 100 & 84 & 180 & 1100 & 71 & 57 & 60 & 47 \\
\hline$F$ influent & 1100 & 1300 & 46 & 170 & 200 & 230 & 1100 & 56 & 47 & 47 & 32 \\
\hline $\begin{array}{l}\text { Removal rate } \\
(\%)\end{array}$ & $53 \%$ & $48 \%$ & $84 \%$ & $41 \%$ & $58 \%$ & $22 \%$ & $0 \%$ & $-27 \%$ & $-20 \%$ & $-28 \%$ & $-49 \%$ \\
\hline $\begin{array}{l}\text { Method } \\
\text { Detection } \\
\text { Limit (MDL) }\end{array}$ & 0.8 & 0.2 & 3.3 & 3.1 & 1.2 & 2.0 & 1.2 & 0.1 & 0.4 & 0.2 & 1.1 \\
\hline $\begin{array}{l}\text { Method } \\
\text { Quantification } \\
\text { Limit (MQL) }\end{array}$ & 2.2 & 0.7 & 8.7 & 8.2 & 3.3 & 5.2 & 3.3 & 0.2 & 0.9 & 0.6 & 3.0 \\
\hline $\begin{array}{l}\text { Average } \\
\text { removal rate } \\
(\%)\end{array}$ & $35 \%$ & $36 \%$ & $-10 \%$ & $40 \%$ & $24 \%$ & $30 \%$ & $7 \%$ & $-16 \%$ & $-15 \%$ & $-26 \%$ & $-43 \%$ \\
\hline LogKow & 3.18 & 1.64 & 2.48 & 0.73 & 4.51 & 3.18 & 0.65 & 2.25 & 1.42 & 1.42 & 0.95 \\
\hline $\begin{array}{l}\text { Max removal } \\
\text { rate (\%) }\end{array}$ & $53 \%$ & $57 \%$ & $84 \%$ & $64 \%$ & $58 \%$ & $50 \%$ & $19 \%$ & $-1 \%$ & $0 \%$ & $-14 \%$ & $-18 \%$ \\
\hline $\begin{array}{l}\text { Min removal } \\
\text { rate (\%) }\end{array}$ & $24 \%$ & $18 \%$ & $-59 \%$ & $20 \%$ & $9 \%$ & $17 \%$ & $0 \%$ & $-30 \%$ & $-28 \%$ & $-38 \%$ & $-73 \%$ \\
\hline $\begin{array}{l}\text { Chemical } \\
\text { STPs }\end{array}$ & $\begin{array}{l}\text { telmi } \\
\text { sartan }\end{array}$ & irbesartan & $\begin{array}{l}\text { olme } \\
\text { sartan }\end{array}$ & valsartan & losartan & $\begin{array}{l}\text { cande } \\
\text { sartan }\end{array}$ & $\begin{array}{l}\text { crotami } \\
\text { ton }\end{array}$ & $\mathrm{DEET}^{\mathrm{b}}$ & TEP $^{\mathrm{c}}$ & TCEP $^{d}$ & TCPPe \\
\hline $\begin{array}{l}\text { A ozonized } \\
\text { water }\end{array}$ & 530 & 210 & $(1.8)$ & 130 & N.D. & 110 & $(4.0)$ & 44 & 21 & 230 & 630 \\
\hline A effluent & 1800 & 470 & 670 & 330 & 76 & 380 & 2000 & 63 & 23 & 230 & 590 \\
\hline
\end{tabular}

a: not detected, b: $N, N$-diethyl-m-toluamide, c: triethyl phosphate, d: tris(2-chloroethyl) phosphate, e: tris(2-chloroisopropyl) phosphate, f: tris(1,3-dichloro-2-pro 


\begin{tabular}{|c|c|c|c|c|c|c|c|c|c|c|c|}
\hline $\begin{array}{l}\text { Chemical } \\
\text { STPs }\end{array}$ & $\begin{array}{l}\text { clarithro } \\
\text { mycin }\end{array}$ & $\begin{array}{l}14- \\
\text { hydroxy } \\
\text { clarithro } \\
\text { mycin }\end{array}$ & $\begin{array}{l}\text { erythro } \\
\text { mycin }\end{array}$ & $\begin{array}{l}\text { trimetho } \\
\text { prim }\end{array}$ & $\begin{array}{l}\text { diclo } \\
\text { fenac }\end{array}$ & $\begin{array}{l}\text { 5- } \\
\text { hydroxy } \\
\text { diclo } \\
\text { fenac }\end{array}$ & sulpiride & $\begin{array}{l}\text { carbama } \\
\text { zepine }\end{array}$ & $\begin{array}{l}2- \\
\text { hydroxy } \\
\text { carbama } \\
\text { zepine }\end{array}$ & $\begin{array}{l}\text { 3- } \\
\text { hydroxy } \\
\text { carbama } \\
\text { zepine }\end{array}$ & $\begin{array}{l}\text { carbamazepine } \\
10,11 \\
\text { epoxide }\end{array}$ \\
\hline A influent & 2100 & 580 & 780 & 2600 & 230 & 340 & 1600 & 300 & 28 & 180 & 870 \\
\hline $\begin{array}{l}\text { Removal rate } \\
\text { by ozone (\%) }\end{array}$ & $71 \%$ & $55 \%$ & $100 \%$ & $61 \%$ & $100 \%$ & $71 \%$ & $100 \%$ & $30 \%$ & $5 \%$ & $0 \%$ & $-7 \%$ \\
\hline $\begin{array}{l}\text { Removal rate } \\
(\%)\end{array}$ & $14 \%$ & $19 \%$ & $14 \%$ & $87 \%$ & $67 \%$ & $-12 \%$ & $-25 \%$ & $79 \%$ & $21 \%$ & $-27 \%$ & $32 \%$ \\
\hline B effluent & 1900 & 680 & 780 & 870 & 170 & 350 & 1800 & 51 & 22 & 160 & 620 \\
\hline B influent & 2600 & 700 & 740 & 3300 & 260 & 300 & 1600 & 670 & 24 & 150 & 680 \\
\hline $\begin{array}{l}\text { Removal rate } \\
(\%)\end{array}$ & $27 \%$ & $3 \%$ & $-5 \%$ & $74 \%$ & $35 \%$ & $-17 \%$ & $-13 \%$ & $92 \%$ & $6 \%$ & $-7 \%$ & $9 \%$ \\
\hline C effluent & 2000 & 600 & 530 & 180 & 160 & 410 & 2000 & 50 & 23 & 140 & 690 \\
\hline C influent & 1700 & 490 & 530 & 3000 & 250 & 360 & 2100 & 410 & 34 & 330 & 650 \\
\hline $\begin{array}{l}\text { Removal rate } \\
(\%)\end{array}$ & $-18 \%$ & $-22 \%$ & $0 \%$ & $94 \%$ & $36 \%$ & $-14 \%$ & $5 \%$ & $88 \%$ & $33 \%$ & $58 \%$ & $-6 \%$ \\
\hline D effluent & 1800 & 700 & 600 & 140 & 35 & 370 & 1800 & 48 & 27 & 150 & 570 \\
\hline D influent & 1900 & 710 & 590 & 4700 & 180 & 310 & 1400 & 400 & 22 & 120 & 410 \\
\hline $\begin{array}{l}\text { Removal rate } \\
(\%)\end{array}$ & $5 \%$ & $1 \%$ & $-2 \%$ & $97 \%$ & $81 \%$ & $-19 \%$ & $-29 \%$ & $88 \%$ & $-22 \%$ & $-25 \%$ & $-39 \%$ \\
\hline E effluent & 1400 & 410 & 560 & 210 & 130 & 300 & 1400 & 36 & 18 & 140 & 420 \\
\hline E influent & 1600 & 450 & 530 & 2300 & 220 & 250 & 1500 & 430 & 23 & 110 & 430 \\
\hline $\begin{array}{l}\text { Removal rate } \\
(\%)\end{array}$ & $13 \%$ & $9 \%$ & $-6 \%$ & $91 \%$ & $41 \%$ & $-20 \%$ & $7 \%$ & $92 \%$ & $23 \%$ & $-27 \%$ & $2 \%$ \\
\hline$F$ effluent & 1400 & 600 & 730 & 73 & 71 & 220 & 1900 & 25 & 22 & 230 & 500 \\
\hline$F$ influent & 1800 & 590 & 730 & 2100 & 250 & 220 & 2000 & 240 & 27 & 120 & 570 \\
\hline $\begin{array}{l}\text { Removal rate } \\
(\%)\end{array}$ & $22 \%$ & $-2 \%$ & $0 \%$ & $97 \%$ & $71 \%$ & $0 \%$ & $5 \%$ & $90 \%$ & $19 \%$ & $-92 \%$ & $12 \%$ \\
\hline $\begin{array}{l}\text { Method } \\
\text { Detection } \\
\text { Limit (MDL) }\end{array}$ & 2.1 & 0.19 & 1.4 & 3.1 & 0.15 & 2.5 & 2.5 & 2.2 & 0.42 & 5.4 & 4.1 \\
\hline $\begin{array}{l}\text { Method } \\
\text { Quantification } \\
\text { Limit (MQL) }\end{array}$ & 5.6 & 0.51 & 3.7 & 8.1 & 0.40 & 6.6 & 6.7 & 5.9 & 1.1 & 14 & 11 \\
\hline $\begin{array}{l}\text { Average } \\
\text { removal rate } \\
(\%)\end{array}$ & $11 \%$ & $1 \%$ & $0 \%$ & $90 \%$ & $55 \%$ & $-14 \%$ & $-8 \%$ & $88 \%$ & $13 \%$ & $-20 \%$ & $2 \%$ \\
\hline LogKow & 8.42 & 5.31 & 3.63 & 3.65 & 4.01 & 4.79 & 2.73 & 2.26 & 0.87 & 1.63 & 2.89 \\
\hline $\begin{array}{l}\text { Max removal } \\
\text { rate (\%) }\end{array}$ & $27 \%$ & $19 \%$ & $14 \%$ & $97 \%$ & $81 \%$ & $0 \%$ & $7 \%$ & $92 \%$ & $33 \%$ & $58 \%$ & $32 \%$ \\
\hline $\begin{array}{l}\text { Min removal } \\
\text { rate (\%) }\end{array}$ & $-18 \%$ & $-22 \%$ & $-6 \%$ & $74 \%$ & $35 \%$ & $-20 \%$ & $-29 \%$ & $79 \%$ & $-22 \%$ & $-92 \%$ & $-39 \%$ \\
\hline
\end{tabular}

Anti-hypertensive agents (telmisartan, irbesartan, olmesartan, valsartan, losartan, and candesartan) presented a wide range of average removal rates (from $14 \%$ for candesartan to $90 \%$ for valsartan). High removal rates for valsartan have been reported in multiple studies; for example, the removal rate was reported to be $90 \%$ by Archer et al. (2017) and approximately $75 \%$ by Kasprzyk-Hordern et al. (2009). Carbamazepine and its metabolites (2-hydroxycarbamazepine, 3hydroxycarbamazepine, and carbamazepine-10,11-epoxide) were scarcely removed, and this trend was also reported by Jelić et al. (2011). The overall concentrations of chemicals were greatly reduced by ozone treatment in STP A. In terms of PFRs, triphenyl phosphate (TPhP), TBOEP, and tricresyl phosphate (TCP) were relatively well removed (average removal rates of $61 \%, 73 \%$, and $75 \%$, respectively). In addition, the ratio of PFRs subjected to biodegradation removal by sewage treatment was almost negligible. For example, the removal rate of triethyl phosphate (TEP) calculated by the EPI suite and attributed to biodegradation was $0.09 \%$, while the total removal rate was $1.87 \%$. Similarly, a TPhP removal rate of $0.56 \%$ was attributed to biodegradation, while the total removal rate was $60.71 \%$. The correlation factor between removal rates and octanol-water partition coefficient (log $\left.\mathrm{K}_{\mathrm{ow}}\right)$ of PFRs was 0.6989 . In contrast, the removal rates obtained by ozonation ranged from $-23 \%$ for tributyl phosphate (TBP) to $38 \%$ for TBOEP, with an overall low value for PFRs. The removal of 
hydrophobic chemicals, such as TBOEP and TBP, was nearly negligible, including that by ozonation. Among PFRs, tris(2-chloroethyl) phosphate (TCEP), tris(1,3-dichloro-2-propyl) phosphate (TDCPP), and tris(2-chloroisopropyl) phosphate (TCPP) were particularly unsusceptible to ozonation (removal rates < 5\%); however, their concentrations were found to be reduced by advanced oxidation processes (AOPs; UV/ $\mathrm{H}_{2} \mathrm{O}_{2}$ treatment) (Yuan et al. 2015). Watts and Linden (2009) determined the second-order rates of reactions of four PFRs (TBOEP, TBP, TCEP, and TCPP) with ultraviolet and ozone-generated $\bullet$ OH in water. Among them, TBOEP was the fastest to react with $\cdot \mathrm{OH}\left(\mathrm{kOH}=1.03 \times 10^{10} \mathrm{M}^{-1} \mathrm{~s}^{-1}\right)$, followed by TCPP, TCEP, and TBP $\left(6.40 \times 10^{9}, 5.60 \times 10^{8}\right.$, and $1.98 \times 10^{8} \mathrm{M}^{-1} \mathrm{~s}^{-1}$, respectively). Yuan et al. (2015) reported the energy consumption for the degradation of PFRs from municipal secondary effluents by ozone and UV/ $\mathrm{H}_{2} \mathrm{O}_{2}$ treatment. They estimated the total cost of the ozone and $\mathrm{UV} / \mathrm{H}_{2} \mathrm{O}_{2}$ treatments (reaction time: $10 \mathrm{~min}$ ) to be 0.344 and $0.279 € \mathrm{~m}{ }^{-3}$, respectively. Therefore, the AOP method can be used to regulate PFR emissions effectively.

\subsection{Mass balance of chemicals in the Tamagawa River in Tokyo}

Figure 2 shows the PPCP loads measured at each sampling point along the Tamagawa River. Six PPCPs exceeded their PNEC at one sampling point at least, and their respective loads were calculated. The load of each sampling point was calculated by multiplying the concentration and the flow rate at that point, whereas the cumulative load indicates the accumulated load of the tributary streams and STPs, starting from Nagata Bridge, which is the most upstream point in this study. When the load of a chemical at a point on the Tamagawa River (Hino, Sekido, or Tamagawara bridges) coincided with the cumulative one, the chemical was considered to flow downstream without degrading, volatilizing, or getting adsorbed on the riverbed. For all chemicals, except diclofenac, the measured load at each point on the Tamagawa River coincided with the cumulative one to a certain extent. The measured loads of diclofenac at Hino, Sekido, and Tamagawara bridges were significantly lower than its cumulative load at each point; the ratios of the measured and cumulative loads at Hino, Sekido, and Tamagawara bridges were $0.33,0.48$, and 0.42 , respectively. Since diclofenac is reported to photodegrade in water environments (Buser et al. 1998; Bartels and Tümpling Jr. 2007), we assumed that it photodegraded while flowing down the river.

\section{Conclusions}

In this study, we conducted a nationwide survey and ecological risk assessment of PPCPs in water environments in Japan. For risk assessment, PNEC values were collected from the reported literature, such as studies on ecotoxicological aspects. For pharmaceuticals whose PNEC values have not been clarified, their PNECs were calculated by conducting bioassay experiments on aquatic organisms. In the risk assessment study, 59 water samples were collected from sampling points throughout Japan and analyzed for chemicals using LC-MS/MS. The PNEC concentration was exceeded at one point, at least, for clarithromycin, 14-hydroxyclarithromycin, erythromycin, diclofenac, carbamazepine, and telmisartan. The removal rates for these chemicals at STPs were investigated by comparing their concentrations in the influent and effluent.

Although many pharmaceuticals and PFRs were not effectively removed by the activated-sludge treatment, almost all of them were decomposed by ozonation, except for certain PFRs. The mass balance of six chemicals, whose concentrations exceeded PNEC at one sampling point at least, was calculated by multiplying the concentration of each chemical and the flow rate through the Tamagawa River. The results indicated that diclofenac is likely photodegraded while flowing down the river. Through this joint research project, many institutes and different industries were able to work together to contribute to a deeper understanding of the ecological risks posed by PPCPs in Japan. The study demonstrated that environmental surveys could be efficiently conducted over a wide area through joint research. However, the study was conducted in winter, and it is known that the discharge of PPCPs into the environment varies with the season (Golovko et al. 2014; Marques dos Santos et al. 2019). Therefore, we plan to conduct a survey in summer to better understand the concentrations, and therefore risks, of PPCPs. In addition, we plan to conduct a survey of wastewater discharged from sites other than STPs, especially commercial sites, to better understand the various sources of PPCP emissions.

\section{Declarations}

\section{Ethics approval and consent to participate}

Not Applicable

\section{Consent for publication}

Not Applicable

\section{Availability of data and materials}

All data generated or analyses during this study are included in this published article and its supplementary information files.

\section{Competing interests}

None

\section{Funding}

This study was supported by the Environment Research and Technology Development Fund (JPMEERF20195054) of the Environmental Restoration and Conservation Agency of Japan. 
Conceptualization of the research project, writing the original draft, and funding acquisition were performed by TN. Methodology was performed by MK and YM (PPCP analysis) and TO and AS (bioassay experiments with aquatic organisms). Project administration was performed by MK and YM (Tokyo prefecture), TT (Osaka city), CM (Hyogo prefecture), and HH (Nagoya city). Investigation was performed by DA and MO (Osaka city), YH and TK (Hyogo prefecture), HH (Nagoya city). Review and editing of the manuscript were performed by DA, $\mathrm{YH}$, and $\mathrm{HH}$. AS advised on toxicity information. All authors read and approved the final manuscript.

\section{Acknowledgments}

We are grateful to the regional environmental research institutions for collecting water samples in each region.

\section{References}

1. Agunbiade FO, Moodley B (2014) Pharmaceuticals as emerging organic contaminants in Umgeni River water system, KwaZulu-Natal, South Africa. Environ Monit Assess 186:7273-7291. https://doi.org/10.1007/s10661-014-3926-Z

2. Archer E, Petrie B, Kasprzyk-Hordern B, Wolfaardt GM (2017) The fate of pharmaceuticals and personal care products (PPCPs), endocrine disrupting contaminants (EDCs), metabolites and illicit drugs in a WWTW and environmental waters. Chemosphere 174:437-446. https://doi.org/10.1016/j.chemosphere.2017.01.101

3. Balakrishna K, Rath A, Praveenkumarreddy Y, Guruge KS, Subedi B (2017) A review of the occurrence of pharmaceuticals and personal care products in Indian water bodies. Ecotoxicol Environ Saf 137:113-120. https://doi.org/10.1016/j.ecoenv.2016.11.014

4. Bartels $P$, von Tümpling W (2007) Solar radiation influence on the decomposition process of diclofenac in surface waters. Sci Total Environ 374:143-155. https://doi.org/10.1016/j.scitotenv.2006.11.039

5. Baumann M, Weiss K, Maletzki D, Schüssler W, Schudoma D, Kopf W, Kühnen U (2015) Aquatic toxicity of the macrolide antibiotic clarithromycin and its metabolites. Chemosphere 120:192-198. https://doi.org/10.1016/j.chemosphere.2014.05.089

6. Bendz D, Paxéus NA, Ginn TR, Loge FJ (2005) Occurrence and fate of pharmaceutically active compounds in the environment, a case study: Höje River in Sweden. J Hazard Mater 122:195-204. https://doi.org/10.1016/j.jhazmat.2005.03.012

7. Birch GF, Drage DS, Thompson K, Eaglesham G, Mueller JF (2015) Emerging contaminants (pharmaceuticals, personal care products, a food additive, and pesticides) in waters of Sydney estuary, Australia. Mar Pollut Bull 97:56-66. https://doi.org/10.1016/j.marpolbul.2015.06.038

8. Blair BD, Crago JP, Hedman CJ, Klaper RD (2013) Pharmaceuticals and personal care products found in the Great Lakes above concentrations of environmental concern. Chemosphere 93:2116-2123. https://doi.org/10.1016/j.chemosphere.2013.07.057

9. Carmona E, Andreu V, Picó Y (2014) Occurrence of acidic pharmaceuticals and personal care products in Turia River Basin: From waste to drinking water. Sci Total Environ 484:53-63. https://doi.org/10.1016/j.scitotenv.2014.02.085

10. Carson R (1962) Silent spring. ISBN 978-4102074015

11. Cizmas L, Sharma VK, Gray CM, McDonald TJ (2015) Pharmaceuticals and personal care products in waters: Occurrence, toxicity, and risk. Environ Chem Lett 13:381-394. https://doi.org/10.1007/s10311-015-0524-4

12. Currie LA (1997) Detection: International update, and some emerging di-lemmas involving calibration, the blank, and multiple detection decisions. Chemom Intell Lab Syst 37:151-181. https://doi.org/10.1016/S0169-7439(97)00009-9

13. Deo RP, Halden RU (2013) Pharmaceuticals in the built and natural water environment of the United States. Water 5:1346-1365. https://doi.org/10.3390/w5031346

14. DrugBank (2020) https://go.drugbank.com/. Accessed 2 July 2021

15. Environment Agency of UK (2009) Environmental Risk Evaluation Report: Tricresyl phosphate (CAS no. 1330-78-5). https://assets.publishing.service.gov.uk/government/uploads/system/uploads/attachment_data/file/290861/scho0809bquj-e-e.pdf. Accessed 8 July 2021

16. Environment Canada (2007) Biological test method: Test of reproduction and survival using the cladoceran Ceriodaphnia dubia, 2nd edn. https://www.canada.ca/content/dam/eccc/migration/main/faunescience-wildlifescience/b2d95b23-54e1-4106-b642-8354fbdbe1b8/rm21-202ndedcerioenglish.pdf Method Development and Applications Section, Environmental Science and Technology Centre, Environment Canada, Ottawa. Accessed 11 July 2021

17. Environmental Restoration and Conservation Agency of Japan (2019) Evaluation and management of emerging chemicals by the comprehensive monitoring using local networks (in Japanese). https://www.erca.go.jp/suishinhi/seika/pdf/seika_1_r01/5-1602_2.pdf. Accessed 11 July 2021

18. Eskenazi B, Warner M, Brambilla P, Signorini S, Ames J, Mocarelli P (2018) The Seveso accident: A look at 40 years of health research and beyond. Environ Int 121:71-84. https://doi.org/10.1016/j.envint.2018.08.051

19. Furberg A (2014) Environmental risk assessment of pharmaceutical exposure to fish in the Swedish Göta Älv River. http://publications.lib.chalmers.se/records/fulltext/202348/202348.pdf. Master's thesis, Chalmers University of Technology. Accessed 11 July 2021

20. Golovko O, Kumar V, Fedorova G, Randak T, Grabic R (2014) Seasonal changes in antibiotics, antidepressants/psychiatric drugs, antihistamines, and lipid regulators in a wastewater treatment plant. Chemosphere 111:418-426. https://doi.org/10.1016/j.chemosphere.2014.03.132

21. Government of Japan (2012) Dioxins. https://www.env.go.jp/en/chemi/dioxins/brochure2012.pdf. Accessed 11 July 2021

22. Harada A, Komori K, Nakada N, Kitamura K, Suzuki Y (2008) Biological effects of PPCPs on aquatic lives and evaluation of river waters affected by different wastewater treatment levels. Water Sci Technol 58:1541-1546. https://doi.org/10.2166/wst.2008.742 
23. Houtman CJ (2010) Emerging contaminants in surface waters and their relevance for the production of drinking water in Europe. J Integr Environ Sci 7:271-295. https://doi.org/10.1080/1943815X.2010.511648

24. Japan Sewage Works Association (2013) Design standard for municipal wastewater treatment plants, 2 nd edn. https://www.humanitarianlibrary.org/sites/default/files/2019/05/October-2013-Revised-Design-Standard-of-WWTP2.pdf. Accessed 11 July 2021

25. Jelić A, Gros M, Petrović M, Ginebreda A, Barceló D (2011) Occurrence, partition, and removal of pharmaceuticals in sewage water and sludge during wastewater treatment. Water Res 45:1165-1176. https://doi.org/10.1016/j.watres.2010.11.010

26. Kasprzyk-Hordern B, Dinsdale RM, Guwy AJ (2008) The occurrence of pharmaceuticals, personal care products, endocrine disruptors, and illicit drugs in surface water in south Wales, UK. Water Res 42:3498-3518. https://doi.org/10.1016/j.watres.2008.04.026

27. Kasprzyk-Hordern B, Dinsdale RM, Guwy AJ (2009) The removal of pharmaceuticals, personal care products, endocrine disruptors and illicit drugs during wastewater treatment and its impact on the quality of receiving waters. Water Res 43:363-380. https://doi.org/10.1016/j.watres.2008.10.047

28. Kim JW, Jang HS, Kim JG, Ishibashi H, Hirano M, Nasu K, Ichikawa N, Takao Y, Shinohara R, Arizono K (2009) Occurrence of pharmaceutical and personal care products (PPCPs) in surface water from Mankyung River, South Korea. J Health Sci 55:249-258. https://doi.org/10.1248/jhs.55.249

29. Kim SD, Cho J, Kim IS, Vanderford BJ, Snyder SA (2007) Occurrence and removal of pharmaceuticals and endocrine disruptors in South Korean surface, drinking, and waste waters. Water Res 41:1013-1021. https://doi.org/10.1016/j.watres.2006.06.034

30. Komori K, Suzuki Y, Minamiyama M, Harada A (2013) Occurrence of selected pharmaceuticals in river water in Japan and assessment of their environmental risk. Environ Monit Assess 185:4529-4536. https://doi.org/10.1007/s10661-012-2886-4

31. Loos R, Wollgast J, Huber T, Hanke G (2007) Polar herbicides, pharmaceutical products, perfluorooctanesulfonate (PFOS), perfluorooctanoate (PFOA), and nonylphenol and its carboxylates and ethoxylates in surface and tap waters around Lake Maggiore in Northern Italy. Anal Bioanal Chem 387:1469-1478. https://doi.org/10.1007/s00216-006-1036-7

32. Ma R, Wang B, Lu S, Zhang Y, Yin L, Huang J, Deng S, Wang Y, Yu G (2016) Characterization of pharmaceutically active compounds in Dongting Lake, China: Occurrence, chiral profiling, and environmental risk. Sci Total Environ 557-558:268-275. https://doi.org/10.1016/j.scitotenv.2016.03.053

33. Ma R, Wang B, Yin L, Zhang Y, Deng S, Huang J, Wang Y, Yu G (2017) Characterization of pharmaceutically active compounds in Beijing, China: Occurrence pattern, spatiotemporal distribution, and its environmental implication. J Hazard Mater 323:147-155. https://doi.org/10.1016/j.jhazmat.2016.05.030

34. Mano H, Okamoto S (2016) Preliminary ecological risk assessment of 10 PPCPS and their contributions to the toxicity of concentrated surface water on an algal species in the middle basin of Tama River. J Water Environ Technol 14:423-436. https://doi.org/10.2965/jwet.15-045

35. Marques Dos Santos M, Hoppe-Jones C, Snyder SA (2019) DEET occurrence in wastewaters: Seasonal, spatial, and diurnal variability - Mismatches between consumption data and environmental detection. Environ Int 132:105038. https://doi.org/10.1016/j.envint.2019.105038

36. Ministry of the Environment, Japan (2019) Guidelines for the initial environmental risk assessment of chemicals (in Japanese). http://www.env.go.jp/chemi/report/ierac18/1-2.pdf. Accessed 11 July 2021

37. Miyawaki T, Nishino T, Asakawa D, Haga Y, Hasegawa H, Kadokami K (2021) Development of a rapid and comprehensive method for identifying organic micropollutants with high ecological risk to the aquatic environment. Chemosphere 263:128258. https://doi.org/10.1016/j.chemosphere.2020.128258

38. National Institutes of Health (2020a) ChemIDplus advanced. https://chem.nIm.nih.gov/chemidplus/. Accessed 11 July 2021

39. National Institutes of Health (2020b) PubChem. https://pubchem.ncbi.nlm.nih.gov/. Accessed 11 July 2021

40. Olatunde JO, Chimezie A, Tolulope B, Aminat TT (2014) Determination of pharmaceutical compounds in surface and underground water by solid phase extraction-liquid chromatography. J Environ Chem Ecotoxicol 6:20-26. https://doi.org/10.5897/JECE2013.0312

41. Organization for Economic Cooperation and Development (1998) Test No. 212: Fish, short-term toxicity test on embryo and sac-fry stages, OECD guidelines for the testing of chemicals. Section 2, Organization for Economic Co-Operation and Development Publishing, Paris. https://doi.org/10.1787/9789264070141-en

42. Organization for Economic Cooperation and Development (2011) Test No. 201: Freshwater alga and cyanobacteria, growth inhibition test, OECD guidelines for the testing of chemicals. Section 2, Organization for Economic Co-Operation and Development Publishing, Paris. https://doi.org/10.1787/9789264069923-en

43. Ortiz de García SA, Pinto G, García-Encina PA, Irusta-Mata R (2014) Ecotoxicity and environmental risk assessment of pharmaceuticals and personal care products in aquatic environments and wastewater treatment plants. Ecotoxicology 23:1517-1533. https://doi.org/10.1007/s10646-014-1293-8

44. National Research and Development Agency Public Works Research Institute (2010) Res Results Priority Res Projects (in Japanese). https://www.pwri.go.jp/jpn/results/report/report-project/2010/pdf/pro-8-1.pdf. Accessed 11 July 2021

45. Roberts J, Kumar A, Du J, Hepplewhite C, Ellis DJ, Christy AG, Beavis SG (2016) Pharmaceuticals and personal care products (PPCPs) in Australia's largest inland sewage treatment plant, and its contribution to a major Australian river during high and low flow. Sci Total Environ 541:1625-1637. https://doi.org/10.1016/j.scitotenv.2015.03.145

46. United Nations Environment Programme (2016) The national implementation plan of Japan under the Stockholm convention on persistent organic pollutants. http://chm.pops.int/Portals/0/download.aspx?d=UNEP-POPS-NIP-Japan-COP6.English.pdf. Accessed 11 July 2021

47. Verlicchi P, Al Aukidy M, Zambello E (2012) Occurrence of pharmaceutical compounds in urban wastewater: Removal, mass load and environmental risk after a secondary treatment-A review. Sci Total Environ 429:123-155. https://doi.org/10.1016/j.scitotenv.2012.04.028

48. Watts MJ, Linden KG (2009) Advanced oxidation kinetics of aqueous trialkyl phosphate flame retardants and plasticizers. Environ Sci Technol 43:29372942. https://doi.org/10.1021/es8031659

Page $13 / 15$ 
49. Xie Z, Lu G, Liu J, Yan Z, Ma B, Zhang Z, Chen W (2015) Occurrence, bioaccumulation, and trophic magnification of pharmaceutically active compounds in Taihu Lake, China. Chemosphere 138:140-147. https://doi.org/10.1016/j.chemosphere.2015.05.086

50. Yoshimura T (2003) Yusho in Japan. Ind Health 41:139-148. https://doi.org/10.2486/indhealth.41.139

51. Yuan X, Lacorte S, Cristale J, Dantas RF, Sans C, Esplugas S, Qiang Z (2015) Removal of organophosphate esters from municipal secondary effluent by ozone and UV/H2O2 treatments. Sep Purif Technol 156:1028-1034. https://doi.org/10.1016/j.seppur.2015.09.052

52. Zhou JL, Zhang ZL, Banks E, Grover D, Jiang J (2009) Pharmaceuticals residues in wastewater treatment works effluents and their impact on receiving river water. J Hazard Mater 166:655-661. https://doi.org/10.1016/j.jhazmat.2008.11.070

53. Zhou J, Broodbank N (2014) Sediment-water interactions of pharmaceutical residues in the river environment. Water Res 48:61-70. https://doi.org/10.1016/j.watres.2013.09.026

\section{Figures}

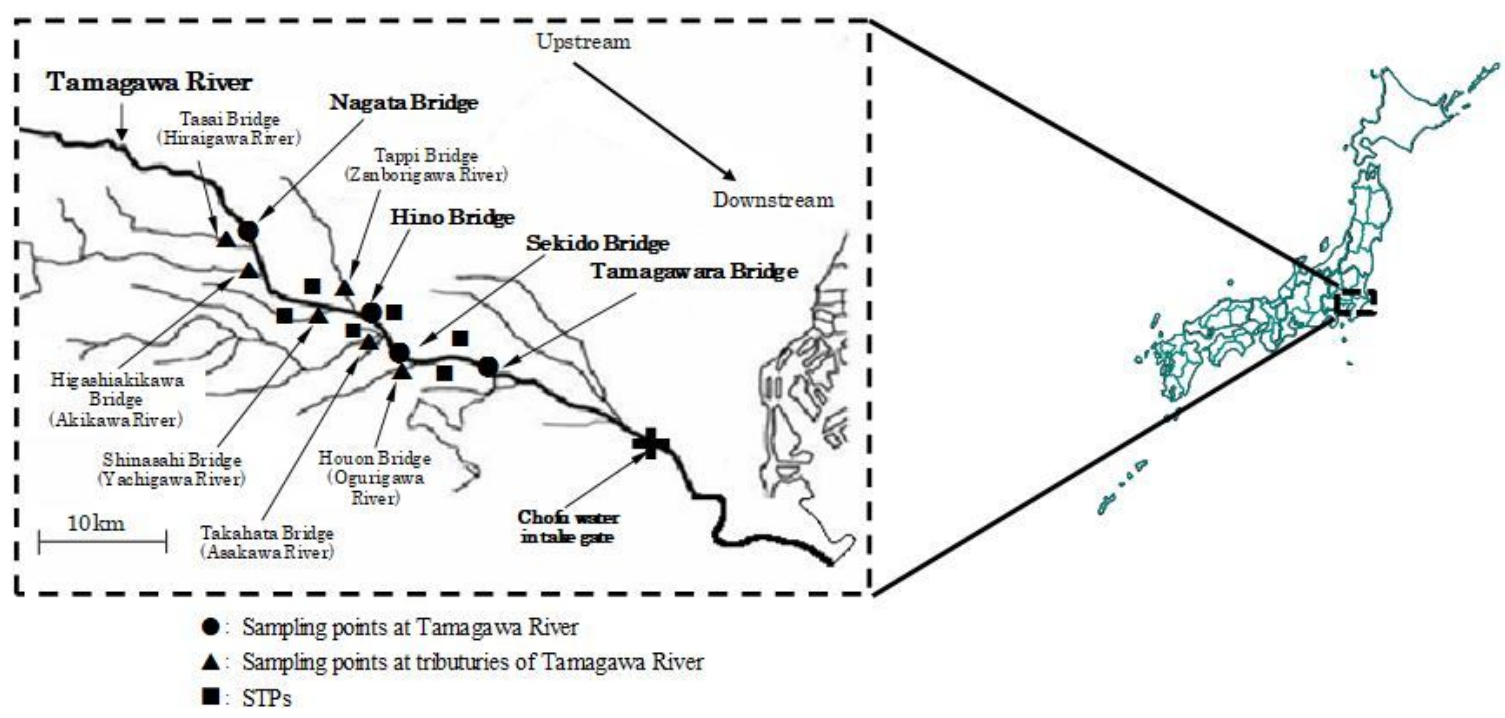

Figure 1

Sampling points in the Tamagawa River Basin 

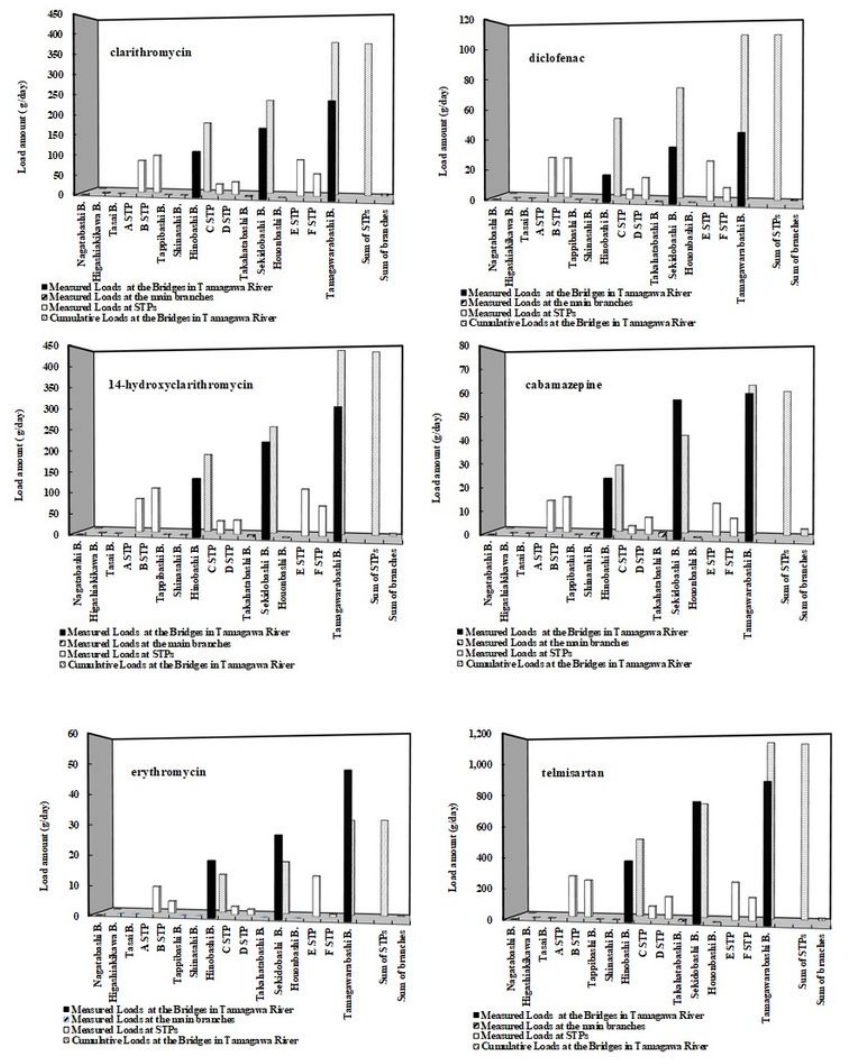

\section{Figure 2}

Cumulative and measured mass loads of PPCPs in water samples obtained at sampling points between the Nagata Bridge and the Tamagawara Bridge

\section{Supplementary Files}

This is a list of supplementary files associated with this preprint. Click to download.

- ESM1.docx 